\title{
Online Learning Platforms' Induced Education Inequalities and Special Education Students' Learning Attitude during Covid-19 Pandemic Homestay in the University of Ibadan
}

\author{
Segun Ojetunde ${ }^{1 *} \quad$ Adebayo Ademidun $^{2} \quad$ Taiwo Sangodoyin ${ }^{1}$ \\ 1.International Center for Educational Evaluation, Institute of Education, University of Ibadan, Nigeria \\ 2.Department of Educational Management, Faculty of Education, University of Ibadan
}

\begin{abstract}
This study investigated some induced education inequalities in online learning platforms among Special Education Students in the University of Ibadan in the wake of the COVID-19 pandemic homestay. All active, special education undergraduate students in the Faculty of Education, made up the study population. Of the entire students within the faculty, 20 students who participated in the online interactions were selected from each level for sampling, making a total of 80 participants. Online questionnaires titled "Classical and Platforms' Induced Inequalities" (CPII, r=0.76) and "Students' Attitude to Learning Scale" (SALS, r=0.72) were developed, validated and deployed. Multinomial regression model constituted the analytical framework, and was interpreted using Relative Risk Ratio (RRR). The findings revealed that: socio-economic status (RRR=2.36, CI: 0.43-13.02) and location $(\mathrm{RRR}=1.19, \mathrm{CI}$ : 0.64-0.57) are classical inequality variables that influenced students' proper attitude to online learning. Also, learning support $(\mathrm{RRR}=1.13, \mathrm{CI}: 0.85-1.58)$ and assessment monitoring ( $R R R=1.47, C I: 1.14-1.91)$ were both online platform-induced inequality variables that influenced students' proper attitude to learning. Therefore, institutions' online learning platform to lessen effects of classical and platform induced impediment to learning should be designed.
\end{abstract}

Keywords: learning attitude, homestay learning, education inequality, online platform

DOI: $10.7176 / \mathrm{JEP} / 12-23-08$

Publication date:August $31^{\text {st }} 2021$

\section{Introduction}

Events or activities become issues in education when they take dimensions different from customary educational practices. Closing down of schools and the attendant expectations of 1.6 billion children and youth out of school all over the globe (Word Bank, 2020) to continue their normal learning activities could be an issue that educators need to contend with. While learners staying at home to wait for teachers' arrival on a platform different from classroom setting could be regarded as a progress-inhibiting issue in education, adoption of remote learning platforms for teaching-learning activities across different school districts and locations, coupled with learners of different socio-economic backgrounds, academic abilities and self-trained mastery of remote learning platforms, could induce complicating variations in learning opportunities. Beyond the above-stated bottlenecks is the tendency of effective assessment monitoring of online testing and examination of learners' achievement to remain questionable if the new normal in education is to stay.

It is projected that by the time it ends, the COVID-19 pandemic would have left indelible mark in the history of epidemic and pandemic diseases. Omojola \& Ojetunde (2020) reported that COVID-19 pandemic does not only cause alarming mortality among infected people, but also has its grip on other key sectors of global economy asides health. The peculiar impacts of the COVID-19 pandemic are the shutting down of the whole economy, including religious gatherings, education sector and other social institutions in response to the state reconfiguration activities rooted in social distance policy. As a result of uncontrollable spread of COVID-19, China instituted a nationwide lockdown, enforcing a system where students' learning was to be transmitted via online platforms on 17 February, 2020. By April 27, their schools were reopened to prepare their students for college entrance exams.

Basilaia \& Kvanvadze (2020) reported that detection of COVID-19 in Georgia, USA led to the suspension of the face-to-face learning in Georgia from 2nd March, 2020 by the recommendation of the Ministry of Education, Science, Culture and Sport of Georgia (MES 2020, the official statement of the Minister). The situation is similar but not the same in Africa. United Nations Economic Scientific and Cultural Organisation (UNESCO, 2020) reported that Africa was the only continent where all countries opted for nationwide school lockdown in view of the situation compelling an embrace of online learning while learners were still at home. Sequel to this, at the level of primary and secondary schools, different initiatives have been introduced to facilitate learning on radio and television stations as substitutes for conventional face-to-face interactions in schools. The practice attracted different nomenclatures: "school at home" in Côte d'Ivoire, "school on TV" in Cameroon, "learning at home" or "teachers' room" in Senegal, "school at home" in Togo, "school on-screen" in Benin Republic (Omojola \& Ojetunde, 2020). 
Response from higher institutions stakeholders was however different from their primary and secondary counterparts. Universities and other tertiary institutions were not quick enough in their reaction compared to other levels of education, perhaps owing to the thinking that teaching in higher education level could be ineffective through non-traditional methods. Recently, due to wide spread realization that the COVID-19 pandemic might stay longer than expected and the phantom reality of its second wave, stakeholders in higher education in Nigeria opted for the migration of teaching-learning interaction from traditional classrooms to online platforms. Ordinarily, most special education students were already victims of various learning challenges capable of impeding their effective learning before the advent of COVID-19 pandemic. It therefore, hypothesized that the challenges associated with online teaching-learning are likely to affect special education students' learning attitude due to technicalities required to access learning platforms. The unavoidable need for learners and teachers to stay at home and provide alternative means of teaching-learning interactions advanced the use of various learning platforms for primary, secondary and tertiary education levels as it could be seen in the Table 1.

Table 1: Varieties of Learning Platforms Adopted for Online Learning

\begin{tabular}{|c|c|c|c|c|c|}
\hline Tools Used & Description & Connectivity & Platform & $\begin{array}{l}\text { Conditions } \\
\text { of Use }\end{array}$ & $\begin{array}{l}\text { Target } \\
\text { Group }\end{array}$ \\
\hline $\begin{array}{l}\text { Internet } \\
\text { (Websites) } \\
\text { YouTube (Most } \\
\text { universities) }\end{array}$ & $\begin{array}{l}\text { Leaners Learn on } \\
\text { their own at home }\end{array}$ & Online & $\begin{array}{l}\text { Desktop/ } \\
\text { Laptop/ } \\
\text { Mobile }\end{array}$ & $\begin{array}{l}\text { All rights } \\
\text { reserved }\end{array}$ & $\begin{array}{l}\text { Tertiary/ } \\
\text { primary/ } \\
\text { secondary }\end{array}$ \\
\hline $\begin{array}{l}\text { Microsoft } \\
\text { Teams }\end{array}$ & $\begin{array}{l}\text { Used mainly by } \\
\text { staff and learners in } \\
\text { tertiary institutions } \\
\text { to hold discussions }\end{array}$ & Online & $\begin{array}{l}\text { Desktop/ } \\
\text { Laptop/ } \\
\text { mobile }\end{array}$ & Freemium & Tertiary \\
\hline Skype & $\begin{array}{l}\text { Used mainly by } \\
\text { Staff and learners in } \\
\text { tertiary institutions } \\
\text { to hold discussions }\end{array}$ & Online & $\begin{array}{l}\text { Desktop/ } \\
\text { Laptop/ } \\
\text { Mobile }\end{array}$ & $\begin{array}{l}\text { Freemium/ } \\
\text { All rights } \\
\text { reserved }\end{array}$ & Tertiary \\
\hline $\begin{array}{l}\text { WhatsApp } \\
\text { groups }\end{array}$ & $\begin{array}{l}\text { Used mainly by } \\
\text { staff and learners in } \\
\text { tertiary institutions } \\
\text { to hold discussions }\end{array}$ & Online & $\begin{array}{l}\text { Desktop/ } \\
\text { Laptop } \\
\text { mobile }\end{array}$ & $\begin{array}{l}\text { All rights } \\
\text { reserved }\end{array}$ & Tertiary \\
\hline Zoom & Group discussions & Online & Desktop & Freemium & Tertiary \\
\hline
\end{tabular}

Source: Mhlanga and Moloi (2020) COVID-19 and the Digital Transformation of Education: What are we Learning on 4IR in South Africa?

According to Brooks, Webster, Smith, Woodland, Wessely, \& Greenberg (2020), being forced to stay at home leads to negative psychological effects such as fear, frustration and anger. The authors reported further that confinement can have long-lasting negative effects. Hu \& Hui (2012)'s study on how Americans spend their time revealed that children's learning behaviour at home is different from the school.

Not only that the homestay could induce psychological drawbacks on students' learning effectiveness, it has also been argued by Akinyemi \& Ojetunde (2020) that variations may exist in students' attitude to learning as a result of home-related factors. Moreover, teachers' methods in the adoption of remote learning platforms can be a factor too. These authors added that variations may create a new set of inequalities in education. Traditionally, inequality in education which is the variation in opportunity to learn occurs as a result of differentials in socioeconomic backgrounds, locations, academic abilities (intelligence) and so on. As the global situation now demands the use of technology for teaching-learning activities through remote platforms in educational institutions, it is imperative to note that the system may have come to last beyond the COVID-19 pandemic. It is therefore not impossible that remote learning platforms heighten the classical (existing) education inequalities or induce newer ones on their own.

Both classical and platform-induced inequalities occur due to difference in locations, socio-economic backgrounds, internet network strength, usage savvy as well as quality of platforms accessing gadgets. All these affect students' attitudes to learning, directly or indirectly through students' access to online platforms, learning support and assessment monitoring procedures. Denial of access to online platforms for learning is a common experience of most learners in developing countries during COVID-19 homestay as observed by Aldama (2020) and Kelly (2020). This may be rooted in factors such as location, inability to subscribe for internet network data and inconsistent savvy remote internet network. Similar experience was reported in the developed countries, Aldama (2020) reported prevalence of digital inequality otherwise known as homework gap in the United States: an access problem faced by students when there is a barrier in performing academic duties due to internet problem at home. 
Kelly (2020) shared a similar sentiment with respect to the United Kingdom where it was observed that around 1.9 million households lacked access to the internet and were relying on pay-as-you-go services, a situation which created bottleneck in accessing online platforms during homestay learning. In the developing countries such as Nigeria, the general experience was erratic internet services due to irregular network and power supply, most especially in rural areas where all these amenities and facilities are in serious dearth. It should be noted that continuous denial of access to learning platforms could affect students' attitude to learning, as this could lead to incessant frustration and inability to meet up with the lesson.

Another variance associated with the adoption of online learning platforms is the differential learning support received by students. Although United Nations (UN 2015) identified large gaps in education access and achievement based on ethnicity and race that derive from the historical and structural exclusion and discrimination. However, in 2020, United Nations emphasizes the need for psychological, social and emotional well-being and supports for all members of the education community: students, families, teachers and education assistants (ECLAC/UNESCO, 2020). Ordinarily, learners enjoy support from both teachers and parents whether during classroom lessons or home assignments. The adoption of online platforms limits learning supports received to parents only, which also differ based on socio-economic backgrounds, parents' level of education and family size. The same situation equally applies to settings where internet resources for online learning are at deficit, compared with the high socio-economic status of parents with enough resources and few household members (Chronicle, 2020)

Arkorful \& Abaidoo (2014) reported that e-learning may also deteriorate institutions' socialization role as well as instructors' role as facilitators of learning activities. This occurs when learning interaction is devoid of individualization of teaching and support to academically weak learners. Also (Lung-Yu Li \& Long-Yuan Lee, 2016) submitted that the most noticeable condemnation of e-Learning is the complete absence of vital personal interactions, not only between learners and instructors, but also among learners. The importance of collective learning has been stressed by $\mathrm{Wu}(1998)$ who submitted that through the process of collective learning, emotions, behaviours, likes and dislikes are expressed; then attitudes are formed.

More so, the aspects of online assessment format and monitoring could be an issue that educators need to contend with during online assessment, as it may eventually affect students' attitude to learning. Timmis, Broadfoot, Sutherland and Oldfield (2016) reported that although technology has been used earlier to support teaching and learning, the assessment aspect is often under-developed. This could lead to bias assessment of students' performance particularly in a situation where they cheated as a result of difficulty in monitoring their online test activities towards eliminating such possibilities (Westga, 2010). More so, possibility of students learning during the pandemic-induced homestay depends on the learner's attitude. A positive attitude increases learning aspirations and the tendency to long for further learning tasks (Lung-Yu Li \& Long-Yuan Lee, 2016). A negative attitude on the other hand, may occur in a situation where learners cheated during test/examination. This could discourage their attitude to learning due to the tendency to subsequently rely on examination malpractice for future successes. Therefore, it was hypothesized that: education inequalities manifesting through traditional or online platform-induced means, could take advantage of students' inability to access learning platforms, lack of learning support and poor assessment monitoring to influence students' attitude to learning and other learning outcomes.

\subsection{Statement of the Problem}

Despite getting priority attention globally, in the wake of the COVID-19 intensity, government and independent education stakeholders in Nigeria never accorded remote learning its deserved attention. Even after its checkered introduction, usage of its platforms met with stiff indifference among users - a situation stakeholders and government have yet to find solutions to. Against the backdrop of adoption challenges facing remote learning platforms in Nigeria, education stakeholders in the United States have advanced the approach and still continue to do so through research. Education stakeholders in the US and other advanced countries have advanced the homestay system in reaction to the emergency shutting down of educational institutions alongside other key sectors accompanying the pandemic. It is therefore perceived that the shift from on-site to online mode of learning under the intense fear of potentially unsafe immediate learning environment, may create individual differences in brain functioning and attitude to learning due to differing responses to distressing external environment.

In addition, teachers' lack of requisite IT skills for onboarding and integrating students into the new learning system before the advent of the COVID-19 pandemic was also reported (Gewin, 2020). This situation, if not taken into adequate consideration, could take advantage of differentials in socio-economic backgrounds, academic abilities, quantity and quality of available platforms, connection gadgets and level of self-efficacy in the use of remote/online platforms to heighten existing inequalities among students or induce newer ones due to variation in students' access to online learning platforms, learning support received from parents and differential assessment monitoring to stem their attitude to learning. Therefore, this study examined effects of classical and 
online learning platforms-induced education inequalities on students' learning attitudes during COVID-19 pandemic homestay through an in-depth study of special education students in the University of Ibadan, Nigeria.

\subsection{Research Questions}

The following research questions were raised to guide the study.

1. Which of the classical education inequality variables (Socio-Economic Status (SES), Location, Academic ability and Internet network availability) influenced students' learning attitudes during COVID-19 induced homestay learning interaction?

2. Were platforms-induced education inequality variables (access to learning platforms, Learning Supports and Assessment monitoring) able to influence attitude to learning among special education students in the University of Ibadan during online learning interaction brought about by COVID-19 homestay?

\subsection{Methodology}

The study adopted descriptive survey design of a population of all undergraduate students in the Faculty of Education, University of Ibadan. Cross-sectional study of University of Ibadan undergraduate students in Special Education during the first semester, 2020/2021 academic session was conducted. The sample population accounted for the set of students that received lectures on the online learning platforms during COVID-19 pandemic homestay. Special Education students were purposively selected for their diverse personal characteristics. Also, 20 students from each of the four academic levels were randomly selected for the study to make the total sample of 80 participants

Two research instruments were designed and validated using the Cronbach Alpha reliability analysis. The instruments include Classical and Platforms'-Induced Inequalities Questionnaire (CPIIQ, r=0.76) which comprises of three sections containing six items each. The items elicited responses on students' access to learning platform during online interaction, learning support students received and assessment monitoring and the Students' Attitude to Learning Scale (SALS, r=072) which comprise of 10 items that elicited responses on students' attitude to learning during COVID-19 homestay. The validated instruments were administered to students in electronic format (Google Form) through the help of learning facilitators and students' representatives via their group WhatsApp and learning interaction platforms.

Multinomial outcome analysis was performed on data collected using multinomial logistic regression, also known as polytomous regression. This is appropriate when the dependent variable synchronizes with more than two categories. Scoring on students' attitude, access to learning platforms and assessment monitoring were categorized into three (high, moderate and low) using percentile rank. The model predicts probabilities of the different possible outcomes of a categorically distributed dependent variable, given a set of independent variables. It allows the choice of $\mathrm{K}$ alternatives (three in this study) to be modeled as a set of K-I independent binary choices $((3-\mathrm{I}=2)$ compared with the reference category. In this study, poor attitudes to learning was chosen as a "reference" to students" attitude whereas moderate and proper attitude are compared with it. Multinomial model displays the relative risk ratio $(R R R)$ or exponential $(\beta)$ for the $K-1(3-1=2)$ categories. RRR below 1(0.00-0.99) assumes that the chance for the event to occur in the given categories is low compared to the reference category. In contrast, RRR greater than 1 corresponds to high risk compared to the reference category. Nevertheless, all statistical analyses are interpreted at $95 \%$ confidence interval (CI) or $\mathrm{p}$-value $<0.05$. Otherwise, the differences are not significant.

\subsection{Results}

Results were presented based on the following research questions:

Research Question 1: Which of the classical education inequality variables (SES, Location, Academic Ability and Internet Network Availability) influenced students' learning attitude during COVID-19 induced homestay learning interactions? 
Table 2: Influence of Classical Education Inequalities on Students' Attitude to Learning during COVID19 Homestay

\begin{tabular}{|c|c|c|c|c|c|c|c|c|c|c|c|}
\hline \multirow[b]{3}{*}{ Variables } & \multicolumn{3}{|c|}{ Descriptive statistics } & \multicolumn{4}{|c|}{ Moderate Attitude } & \multicolumn{4}{|c|}{ Proper Attitude } \\
\hline & \multirow{2}{*}{$\begin{array}{l}\text { Low } \\
(\%)\end{array}$} & \multirow{2}{*}{$\begin{array}{r}\text { Mid } \\
(\%)\end{array}$} & \multirow{2}{*}{$\begin{array}{l}\text { High } \\
(\%)\end{array}$} & \multirow[b]{2}{*}{ RRR } & \multirow{2}{*}{$\begin{array}{l}\mathrm{P} \text { - } \\
\text { value }\end{array}$} & \multirow[b]{2}{*}{$\begin{array}{l}\text { Low } \\
\text { B. }\end{array}$} & \multirow[b]{2}{*}{ Up B. } & \multirow[b]{2}{*}{ RRR } & \multirow[b]{2}{*}{$\begin{array}{l}\mathrm{P} \text { - } \\
\text { value }\end{array}$} & \multirow[b]{2}{*}{$\begin{array}{l}\text { Low } \\
\text { B. }\end{array}$} & \multirow[b]{2}{*}{$\begin{array}{l}\text { Up } \\
\text { B. }\end{array}$} \\
\hline & & & & & & & & & & & \\
\hline SES & $\begin{array}{l}6 \\
(7.50)\end{array}$ & $\begin{array}{l}68 \\
(85.0)\end{array}$ & $\begin{array}{l}6 \\
(97.50)\end{array}$ & 0.65 & 0.59 & 1.35 & 3.127 & 2.36 & 0.32 & 0.43 & 13.02 \\
\hline Location & $\begin{array}{l}17 \\
(21.25)\end{array}$ & $\begin{array}{l}32 \\
(40.0)\end{array}$ & $\begin{array}{l}31 \\
(38.75)\end{array}$ & 1.19 & 0.64 & 0.57 & 2.47 & 0.64 & 0.28 & 0.29 & 1.44 \\
\hline $\begin{array}{l}\text { Academic } \\
\text { Ability }\end{array}$ & $\begin{array}{l}5 \\
(6.25)\end{array}$ & $\begin{array}{l}65 \\
(81.25)\end{array}$ & $\begin{array}{l}10 \\
(12.5)\end{array}$ & 1.71 & 0.38 & 0.52 & 5.69 & 1.16 & 0.17 & 0.32 & 4.28 \\
\hline $\begin{array}{l}\text { Internet } \\
\text { Network } \\
\text { Availability }\end{array}$ & $\begin{array}{l}39 \\
(48.75)\end{array}$ & $\begin{array}{l}39 \\
(48.75)\end{array}$ & $\begin{array}{l}2 \\
(2.5)\end{array}$ & 0.42 & 0.11 & 0.15 & 1.22 & 0.58 & 0.86 & 0.11 & 1.15 \\
\hline
\end{tabular}

Table 2 showed the descriptive statistics and the result of multinomial regression for the classical education inequality variables. It could be observed that majority of the sample students $(85.0 \%)$ has moderate socioeconomic status (SES), reside in semi-urban area (40.0\% compared to $21.25 \%$ in rural and $38.75 \%$ in urban) and have average academic ability $(81.25 \%)$ as well as internet network availability $(48.75 \%)$. This is an indication that respondents are average students with respect to academic abilities and socio-economic status. The result of multinomial regression reveals that the chance of having proper attitude to learning increases among students based on socio-economic status $(\mathrm{RRR}=2.36, \mathrm{CI}$ : 0.43-13.02) compared to those that have moderate attitudes. More so, the chance of having moderate attitude to learning increased among students ( $R R R=1.19, \mathrm{CI}: 0.64-0.57)$ based on their location when compared with proper attitude. Again, the chance of having moderate attitude to learning $(\mathrm{RRR}=1.71, \mathrm{CI}$ : 0.52-5.69) increased based on students' academic ability during online learning when compared with proper attitude $(\mathrm{RRR}=1.16, \mathrm{CI}$ : $0.32-4.28)$. From the result, it could be inferred that socioeconomic status and students' academic ability influenced students' chance of having proper attitude while students' residential location has moderate influence and internet network availability has no bearing on students' attitude.

Research Question 2: Were the platforms-induced education inequality variables (access to learning platforms, Learning Supports and Assessment monitoring) able to influence students' attitude to learning during online learning interaction brought by COVID-19 homestay?

Table 3: Influence of Online Platforms Induced Inequalities on Students' Attitude to Learning during COVID-19 Homestay

\begin{tabular}{|c|c|c|c|c|c|c|c|c|c|c|c|}
\hline \multirow[b]{3}{*}{ Variable } & \multicolumn{3}{|c|}{ Descriptive Statistics } & \multicolumn{4}{|c|}{ Moderate Attitude } & \multicolumn{4}{|c|}{ Proper Attitude } \\
\hline & \multirow{2}{*}{$\begin{array}{l}\text { Low } \\
(\%)\end{array}$} & \multirow{2}{*}{$\begin{array}{l}\text { Mid } \\
(\%)\end{array}$} & \multirow{2}{*}{$\begin{array}{l}\text { High } \\
(\%)\end{array}$} & \multirow[b]{2}{*}{ RRR } & \multirow[b]{2}{*}{$\begin{array}{l}\text { P- } \\
\text { value }\end{array}$} & \multirow[b]{2}{*}{$\begin{array}{l}\text { Low } \\
\text { B. }\end{array}$} & \multirow[b]{2}{*}{ Up B. } & \multirow[b]{2}{*}{ RRR } & \multirow[b]{2}{*}{$\begin{array}{l}\text { P- } \\
\text { value }\end{array}$} & \multirow[b]{2}{*}{$\begin{array}{l}\text { Low } \\
\text { B. }\end{array}$} & \multirow[b]{2}{*}{$\begin{array}{l}\text { Up } \\
\text { B. }\end{array}$} \\
\hline & & & & & & & & & & & \\
\hline $\begin{array}{ll}\text { Access to } \\
\text { learning } \\
\text { platforms }\end{array}$ & $\begin{array}{l}32 \\
(40.0)\end{array}$ & $\begin{array}{l}23 \\
(28.75)\end{array}$ & $\begin{array}{l}25 \\
(31.25)\end{array}$ & 0.89 & 0.36 & 0.72 & 1.13 & 0.95 & 0.69 & 0.72 & 1.25 \\
\hline $\begin{array}{l}\text { learning } \\
\text { Support }\end{array}$ & $\begin{array}{l}36 \\
(45.0)\end{array}$ & $\begin{array}{l}18 \\
(22.50)\end{array}$ & $\begin{array}{l}26 \\
(32.50)\end{array}$ & 0.82 & 0.11 & 0.64 & 1.05 & 1.13 & 0.19 & 0.85 & 1.58 \\
\hline $\begin{array}{l}\text { Assessment } \\
\text { Monitoring }\end{array}$ & $\begin{array}{l}38 \\
(47.5)\end{array}$ & $\begin{array}{l}17 \\
(21.25)\end{array}$ & $\begin{array}{l}25 \\
(31.25)\end{array}$ & 1.49 & 0.00 & 1.20 & 1.84 & 1.47 & 0.00 & 1.14 & 1.91 \\
\hline
\end{tabular}

Table 3 showed the result of descriptive statistics and multinomial regression for effects of platforms'induced education inequalities on students' attitude to learning. The result shows that majority of students rated their access to online learning platforms (40.0\%), learning support (45.0\%) and assessment monitoring (47.5\%) low on the scale of high moderate and low. The result is an indication that majority of the students faced platform oriented challenges during online learning. Also, multinomial regression result shows that both learning support given to students ( $R R R=1.13, \mathrm{CI}: 0.85-1.58$ ) and assessment monitoring ( $\mathrm{RRR}=1.47, \mathrm{CI}$ : 1.14-1.91) affected their attitude to learning whereas, students' access to online platforms did not affect students' attitude in any form.

\subsection{Discussions}

The result from Table 2 showed the effect of classical education inequality variables on students' attitude to 
learning due to adoption of online learning platforms for teaching-learning activities during COVID-19 homestay. The finding revealed that students' socio-economic status has high probability of influencing their use of learning platforms, and their attitude to learning. This could be due to the fact that socio-economic status nearly influenced other classical inequality variables. The result corroborated Akinyemi \& Ojetunde (2020) who reported that different levels of socio-economic status can influence students' learning on remote platforms. The authors reported further that students from high socio-economic backgrounds were more likely to have better technology devices to access online platforms as well stand the chance of accessing internet data subscription regularly compared with those from low socio-economic background. It is also not impossible that inequality may exist in a situation where computers and IT equipment at home with many children are in heavy demand from parents, children, and other relatives who have to work from home. The same situation equally applies to settings where internet infrastructures or resources to facilitate online learning are at deficit compared with the high socio-economic status parents that have enough resources and few household members (Chronicle, 2020). Also, result from Table 2 reveals that academic ability play significant role in influencing students' attitude to learning. This could be as a result of the fact that students that have high academic ability have high tendency to learn easily compared with those with low academic abilities irrespective of their socio-economic background. The result reveals further that of location of seem to be moderate on students' attitude to learning. This could be due to the fact that high socio-economic status tends to attenuate the effect of location on attitude to learning.

Findings from Table 3 showed that assessment monitoring and learning support have pronounced effects on students' attitude to learning during COVID-19 homestay. The result could be due to the fact that most lecturers did not have prior training before the adoption of online platform for teaching (Gewin, 2020). Therefore, the aspects of learning support and assessment monitoring could be major challenges faced. This finding supports Timmis, Broadfoot, Sutherland and Oldfield (2016) who reported that assessment could constitute serious issue among students and lecturers. This is possible in a situation where some students cheated and by so doing shortchanged their own ability to study hard in their subsequent learning endeavours or discourage hard working students who did not cheat but scored lower than their academically weak contemporaries.

Assessment monitoring could indirectly affect students' attitude when the level of confidence lecturers put in online assessment result is low, thereby resulting in the demand for other means of assessing students' ability. This is situation called for repeated testing. The finding also showed that learning support was key to students' attitude-associated online learning. However, this is rooted in lecturers' prior training and experience in the use of online assessment. Nevertheless, learning support especially during COVID-19 induced homestay could have emanated from parents who determined students' socio-economic status. For instance, learners who come from parents or guardians either not educated, or are financially incapacitated to provide academic material or technical assistance, could underachieve when compared with learners that have parents that is well educated (Akinyemi \& Ojetunde, 2020).

Furthermore, findings on access to online platform revealed that access to learning platforms did not affect students' attitude to learning. The finding further confirmed the result of descriptive statistics, most specifically the fact that almost all the students had access challenges during COVID-19 induced homestay online learning. It surprisingly did not generate variations in students' attitude to learning. The result contradicts Aldama (2020) that reported a prevalence in digital inequality, otherwise known as homework gap in the United States-an access problem faced by students when there is a barrier in performing academic duties due to internet problem at home.

\subsection{Recommendations}

Based on the findings of the study, recommendation could be made that:

1. Stakeholders in special education should make more effort to provide resources or facilities that will improve students' access to online learning platform, in the event that the online learning tradition continues even after the COVID-19 pandemic is over.

2. Online assessment monitoring should be improved to increase the level of confidence stakeholders put on students' online assessment result.

3. Stakeholders in special education at the higher institution level should devise a built-in mechanism to improve students' online learning, independent of students' socio-economic background or other associate factors.

4. Institutions should design their personalized online learning platforms towards lessening the effects of classical and platform induced impediment to effective students' online learning.

\subsection{Conclusion}

Based on the findings of the study, it suffices to conclude that socio-economic status and academic abilities remained key distinguishing inequality variables among students and could generate variations in both their learning attitudes and other learning outcomes. More so, use of online learning platforms among special 
education students, induced challenges of inadequate support from lecturers, coupled with ineffective assessment monitoring that may cause unfair and biased assessment of students' abilities. It could be concluded further, that majority of the students experienced challenges in accessing platforms; therefore, students' learning attitude did not vary based on the access to learning platforms.

\section{References}

Akinyemi, A. L \& Ojetunde, S.M. (2020). Techno-pedagogical models and influence of adoption of remote learning platforms on classical variables of education inequality during COVID-19 Pandemic in Africa. Journal of Positive psychology, Vol. (6)1, 73-83

Aldama, P. (2020). [Opinion] What will happen to poor students when schools go online? Accessed on 24 July. Retrieved from https://rappler.com/voices/ispeak/opinion-poor-students-schools- online- coronavirus.

Arkorful, V\& Abaidoo, N. (2014). The role of e-learning, the advantages and disadvantages of its adoption in Higher Education. International Journal of Education and Research. Vol. 2(2) 48-62 No. 12

Basilaia, G. \& Kvavadze, D. (2020). Transition to online education in schools during a SARS- CoV-2 Coronavirus (COVID-19) pandemic in Georgia. Journal of Pedagogical Research, Vol. (5)4, 16-38

Brooks, S. K., Webster, R. K., Smith, L. E., Woodland, L., Wessely, S., \& Greenberg (2020). The psychological impact of quarantine and how to reduce it: rapid review of the evidence. The Lancet 395, 912-920. doi: 10.1016/S0140-6736(20)30460-8.

Chronicle (2020). As coronavirus spreads, the decision to move classes online is the first step. What comes next? Accessed: March 6, 2020: https://www.chronicle.com/article/As- Coronavirus-Spreads-the/248200.

ECLAC/UNESCO (2020). Education in the time of COVID-19, COVID-19 situation Report, August, 2020

Gewin V. (2020). Five tips for moving teaching online as COVID-19 takes holds nature. 2020, [Epub ahead of print]:10.1038/d41586-020-00896-7Will the coronavirus make online education......Is this from Journal/internet sourced/book?

Hu, P. J.-H., \& Hui, W. 2012. Examining the role of learning engagement in technology- mediated learning and its effects on learning effectiveness and satisfaction. Decision Support Systems, 53(4), 782- 792.

Kelly, A. (2020). Digital divide 'isolates and endangers' millions of UK's poorest. .. Retrieved from https://www.theguardian.com/world/2020/apr/28/digital-divide-isolates-and- endangers-millions-of-ukpoorest. on the ..day, ..month.., year

Lung-Yu Li and Long-Yuan Lee (2016). Computer literacy and online learning attitude toward GSOE students in distance education programs. Canadian Center of Science and Education. Higher Education Studies; Vol. (6) $3,34-51$

MES. (2020). Ministry of Education, Science, Culture and Sport of Georgia. 'Ministry of Education, Science, Culture and Sport of Georgia to strengthen distance learning methods'. Retrieved on 2 April 2020 from https://www.mes.gov.ge/content.php?id=10271\&lang=eng

Omojola, F O \&and Ojetunde, S M (2020). Pareto-Criterion and impact evaluation of effects of COVID-19 pandemic on education and economy. International Journal of Educational Benchmark Vol. 16(, No.2)99119

Timmis S, Broadfoot, P., Sutherland R. and Oldfield, A. (2016). Rethinking assessment in a digital age: opportunities, challenges and risks. Br Education ReReviewss Journal, 42:454-476.

ECLAC/UNESCO (2020). Education in the time of COVID-19, COVID-19 situation Report, August, 2020

UNESCO. (2020). UNESCO Report, 'COVID-19 Educational disruption and response'. Retrieved from https://en.unesco.org/covid19/educationresponse/......insert 16 July, 2020

Wang, C., Pan, R., Wan, X., Tan, Y., Xu, L., Ho, C. S., et al. (2020). Immediate psychological responses and associated factors during the initial stage of the 2019 coronavirus disease (COVID-19) epidemic among the general population in China. Internationalt. Journal. Environmental. Reviews. Public Health Vol. 17, : No. 1729.

Westga (2010). Cheating in the digital age: do students cheat more in online courses? Westga Accessed:March9,2020:https://www.westga.edu/ distance/ojdla/spring131/watson131.ht

WHO (2020) Accessed: March 9, 2020 tttps://www.westga.edu/ distance/ojdla/spring131/watson131.h

WHO (2020), July situation report WHO Coronavirus Disease (COVID-19) Dashboard. www.whoorganization. Coronavirus/situation report.

Wu, C. J. (1998). The learning attitude of students in secondary school. Taiwan Education Review, 566, 44 -50. 